Original Research Paper

\title{
Organic Fertilizers: An Agroecological and Commercial Bet On Smallholders in the Sumapaz Region
}

\author{
${ }^{1}$ Elizabeth Ann Escobar Cazal, ${ }^{2}$ Taha Ahmadi, ${ }^{1}$ Diego Fabián Bejarano Morales, \\ ${ }^{3}$ Gonzalo Escobar Reyes and ${ }^{4}$ Natalia Escobar Escobar \\ ${ }^{1}$ Faculty of Administrative, Economic and Accounting Sciences, University of Cundinamarca, 18th \\ Diagonal \# 20-29, Fusagasuga, Colombia \\ ${ }^{2}$ Faculty of Electronic Engineering, University of Cundinamarca, 18th Diagonal \# 20-29, Fusagasuga, Colombia \\ ${ }^{3}$ Faculty of Education, University of Cundinamarca, 18th Diagonal \# 20-29, Fusagasuga, Colombia \\ ${ }^{4}$ Faculty of Agricultural Sciences, University of Cundinamarca, 18th Diagonal \# 20-29, Fusagasuga, Colombia
}

Article history

Received: 09-04-2020

Revised: 06-05-2020

Accepted: 19-05-2020

Corresponding Author: Elizabeth Ann Escobar Cazal Faculty of Administrative, Economic and Accounting Sciences, University of Cundinamarca, 18th Diagonal \# 20-29, Fusagasuga, Colombia Email: eescobarc@ucundinamarca.edu.co

\begin{abstract}
The feasibility of an agroecological project is supported, among other factors, by the cost-benefit relationship, which tends to shift profitability paradigms on organic fertilizers within the context of long-term finances. For this purpose, the objective of this paper is to carry out a financial study to market organic fertilizers (compost and vermicompost) in the Sumapaz region. An initial analysis of the production zones is conducted, starting with the qualification of 11 farms with livestock and agricultural production obtained through a stratified random sampling. Later on, this is translated into a financial analysis of the cost-benefit ratio in the marketing and agricultural use of organic fertilizers. In order to develop the project, four stages are designed: A description of the operating cost performance of the fertilizer production process; project's initial investment; projected financial statements; and cost-benefit ratio analysis of organic fertilizer's marketing and agricultural use. Finally, the results of this study will show the profitability. Through a Net Present Value of COP $\$ 442.067 .710$ (USD \$110,000), will be obtained an Internal Rate of Return of $136 \%$ and a cost-benefit ratio of 11.58, which represent economic and environmental benefit compared to agrochemical inputs, through a workable system for small holders.
\end{abstract}

Keywords: Agroecology, Sustainability, Profitability

\section{Introduction}

The Sumapaz region is located in the southwestern area of the Cundinamarca Department (Colombia), representing $8 \%$ of the total area of the department, with an area of $1,807 \mathrm{~km}^{2}$. The Population is 219,374 inhabitants, most of which $(132,422)$ live in urban areas and the rest $(86,952)$, in rural areas. It is composed of ten municipalities: Arbelaez, Cabrera, Fusagasuga, Granada, Pandi, Pasca, San Bernardo, Tibacuy, Silvania and Sibate (Romero et al., 2019).

The region of Sumapaz is characterized by a high diversity of flora, fauna and natural resources; it has the world's largest moorland and a high agricultural and livestock production. However, there is an environmental and agricultural crisis across the region, since conventional production systems prevail and there are no permanent participatory strategies with smallholders or public policies in place that promote agroecological production.

Serna et al. (2016), it is identified that agricultural waste from some farms in transition to be organic is not being properly managed (burning, dumping in water sources, among others), a subject that requires implementation of participatory strategies for organic fertilizers production through techniques like composting and worm composting. The production and marketing of these products add value to waste sustainable management. Therefore, similar to (Nowak et al., 2015), this research is focused on the low production levels of fertilizers presented from three points of view; first, unawareness of the product 
economic, social and environmental benefits; second, high costs of chemical inputs and third, underuse of organic waste produced by farms.

Financial analysis is a key management and analytical tool in any production activity since it establishes present economic conditions and how financial resources should be managed and it contributes to estimate future production irrespective of its scale (Romero et al., 2019). Currently, agricultural production requires a constant performance assessment due to frequent changes in social, political, economic and cultural environments (Rasmussen et al., 2017). The research calculated the organic fertilizer cost-benefit ratio, within the parameters of smallholder's capacity to work as a unit, also comparing sale prices of the agrochemicals mostly used by farmers across the region.

\section{Materials and Methods}

Farms under study with production in transition to be organic are not registered in Bogota's Chamber of Commerce (BCC) (Colombia, 2007), nor in the region's Municipal Units of Agricultural Technical Assistance (UMATAS) (Calle Hoyos et al., 1995). However, the only available database on this type of production belongs to National Vocational Training Agency, SENA of Fusagasuga and an institution that started to promote the only organic market where producers from different municipalities came to participate eight years ago.

The mentioned database is clearly outdated and only 12 organic producers are listed. Therefore, some market visits are done to have a first approach with smallholders; during these meetings, it is stated by some market members that, "Some neighbors were already making progress on the road to organic production or the transition process and some of them were even selling their products in other markets." They also expressed their interest in engaging in participatory projects with continuous production support in pursuit of their sustainability. For the above reasons, a "snowball" sampling was applied (Mujica et al., 2019).

Once a database is consolidated with 71 smallholders interested in engaging in the macro-project called, "Sustainable Management of Production Networks in the Sumapaz Region", an analysis of the main components (Dantzker et al., 2016) is carried out, resulting in three groups (Romero et al., 2019). A stratified random sampling is then performed to select "pilot farms" (Szeląg-Sikora and Cupiał, 2014) obtaining a representative sample of 11 farms. Based on the fieldwork, a farms characterization is carried out to identify production areas. A comparative exercise between the use of organic fertilizers and agrochemical inputs to determine costs and benefits of the financial analysis is also conducted.

Structured Observation, surveys and interviews are identified as primary sources. Farms are visited to observe crops, production areas, etc. Interviews are conducted with landowners, who provided information on aspects such as required labor, raw materials, organic fertilizer's time and production levels, etc., (Nowak et al., 2015). In order to find fertilizers profitability points and produce a 5-year forecast of the optimal profit estimate, a simulation of quantities, prices, costs and expenses is conducted. This exercise provided the fertilizer production level for each farm. The simulation's primary objective is to envision new market-based scenarios (Henckel et al., 2015). Simulation is also helpful in estimating return's performance and Net Present Value (NPV) (Pandit et al., 2020). The financial study considered production variables that indicated areas devots to agriculture, livestock and forestry sectors; based on this data, the area of organic fertilizers to be marketed could be established (Table 1).

Table 1: Farms characterization, location and total area devoted to agriculture, livestock and forestry

\begin{tabular}{|c|c|c|c|c|c|c|}
\hline No & Location & Farm name & $\begin{array}{l}\text { Total Area } \\
\left(\mathrm{m}^{2}\right)\end{array}$ & $\begin{array}{l}\text { Agriculture } \\
\text { Área }\left(\mathrm{m}^{2}\right)\end{array}$ & $\begin{array}{l}\text { Livestock } \\
\text { Área }\left(\mathrm{m}^{2}\right)\end{array}$ & $\begin{array}{l}\text { Forestry } \\
\text { Área }\left(\mathrm{m}^{2}\right)\end{array}$ \\
\hline 1 & Fusagasugá/Cucharal & El Gualanday & 11.500 & 6.500 & 3.000 & 2.000 \\
\hline 2 & Granada/Santa Fe & Santa María & 45.000 & 25.600 & 12.400 & 7.000 \\
\hline 3 & Silvania/Noruega Baja & El Caucho & 30.000 & 30.000 & 0 & 0 \\
\hline 4 & Arbeláez/El Vergel & La Isabela & 198.400 & 32.000 & 147.200 & 19.200 \\
\hline 5 & Fusagasugá/Sardinas & Patio Bonito & 32.000 & 25.600 & 3.200 & 3.200 \\
\hline 6 & Granada/Sabaneta & Sabaneta & 22.000 & 12.000 & 6.000 & 4.000 \\
\hline 7 & $\begin{array}{l}\text { Fusagasugá/San José } \\
\text { Piamonte }\end{array}$ & Villa Carmen & 28.800 & 28.800 & 0 & 28.800 \\
\hline 8 & Tibacuy/La Gloria & San Francisco & 30.000 & 20.000 & 0 & 10.000 \\
\hline 9 & Pasca/San Pablo & Villa Juliana & 12.800 & 12.800 & 0 & 0 \\
\hline 10 & Arbeláez/Salitre & El Recreo & 130.000 & 15.000 & 10.000 & 115.000 \\
\hline 11 & Arbeláez/La Victoria & El Consentido & 35.200 & 9.600 & 0 & 0 \\
\hline
\end{tabular}




\section{Results and Discussion}

Operating costs are focused on the fertilizer's production process. Therefore, observing their performance to establish the right volume of direct and indirect materials that will be required is essential to select the appropriate production levels (quantities) that produce a low unit cost and result in profits. The performance of indicators such as costs, revenues, expenses, expenditures and profits is important to determine actions or strategies in order to anticipate opportunities or problems found through financial statements analysis.

Figure 1 represents performance-relevant variables in the financial analysis: Sales, costs, administrative expenses, selling expenses and profits. It can be seen that profits exceed costs and expenses, taking the fifth year as an important result, which showed that agricultural production will have the capacity to be self-sustainable.

The higher the volume of fertilizer produced, the lower the unit cost and therefore, the final selling price will also be lower. The above statement is considerable in composting (product $\mathrm{A}$ ), since in worm composting (product $\mathrm{B}$ ) there are costs that, by increasing quantities produced, selling price also increases. For the average farmer, composting is easier. Production quantities or volumes are established through a simulation of possible relevant scenarios to find a break-even point to forecast future quantities to be produced, however, increasing such capacity each year (Table 2).

In order to make a 5-year-production estimate, each farm should have a minimum capacity to ensure a fair distribution of profits. It is worth noting that each farm has its own supplies and no external materials are needed, which indicates a clean production that is also safe for workers and consumers' health.

These results are consistent with those obtained in the work of (Eraso-Cabrera et al., 2014) and (Bosc et al., 2019). Organic agriculture is a proposal that aims at improving food quality as well as the environment.
Fertilizer production from organic waste is a real example of this situation in the region. Agriculture is ruled by four basic principles: First, maximizing people's own resources (inward oriented); second, avoiding reliance on external inputs by using what is available and becoming an agricultural supplies producer; third, causing the least possible impact when making modifications to the place and environment; and fourth, not endangering producer or consumer's health (Giller et al., 2020). Organic farming, as a relevant subject, aims at making better use of a farm's own resources such as organic fertilizers.

In the evaluation criteria, it is determined that the cost-benefit ratio is the main indicator, which would result in a positive value for production, marketing and as a substitute for agrochemical supplies, since this research objective is to find organic fertilizers profitability for both seller and buyer. We concur with this view with (Murillo et al., 2008), which states, "In the case of organic waste-based fertilizers, chemical fertilizers are the main substitutes."

Cash flow assessment is carried out with three basic indicators: First, Net Present Value (NPV), which represents the monetary value that will be received from the investment (it must be a positive value); second, the Internal Rate of Return (IRR), which refers to the percentage value obtained from the investment (this should be higher than the opportunity cost, which is favorable); the last and most important is the CostBenefit Ratio (CBR), which shows if the benefits or profits outweigh the cost (it should be greater than 1). Financial assessment determined project investment feasibility; it also led investors to see the composting project as a profitable investment opportunity. Effective financial forecasting offers multiple advantages, not only to the company that is preparing the forecasts, but also to creditors and potential investors (Lahmar et al., 2012). Thus, relevant indicators are presented in Table 3.

Table 2: Projection of organic fertilizer quantities produced in 50-kilogram bags

\begin{tabular}{lllllll}
\hline PRODUCTO & Month & Year 1 & Year 2 & Year 3 & Year 4 & Year 5 \\
\hline A (Composting) & 3.300 & 29.700 & 43.560 & 47.916 & 52.708 & 57.978 \\
B (worm composting) & 110 & 990 & 1.452 & 1.597 & 1.757 & 1.933 \\
TOTAL & 3.410 & 30.690 & 45.012 & 49.513 & 54.465 & 59.911 \\
\hline
\end{tabular}

Table 3: Project cash flow analysis

\begin{tabular}{llll}
\hline & Effective net flow & NPV & IRR \\
\hline Year 0 & $-\$ 41.785 .620$ & $\$ 442.067 .710$ & $136 \%$ \\
Year 1 & $\$ 23.155 .140$ & & \\
Year 2 & $\$ 69.309 .207$ & & \\
Year 3 & $\$ 122.853 .285$ & & \\
Year 4 & $\$ 195.225 .543$ & & \\
Year 5 & $\$ 289.698 .060$ & & \\
Initial investment & $\$ 41.785 .620$ & & \\
Opportunity cost & $10 \%$ & & \\
\hline
\end{tabular}




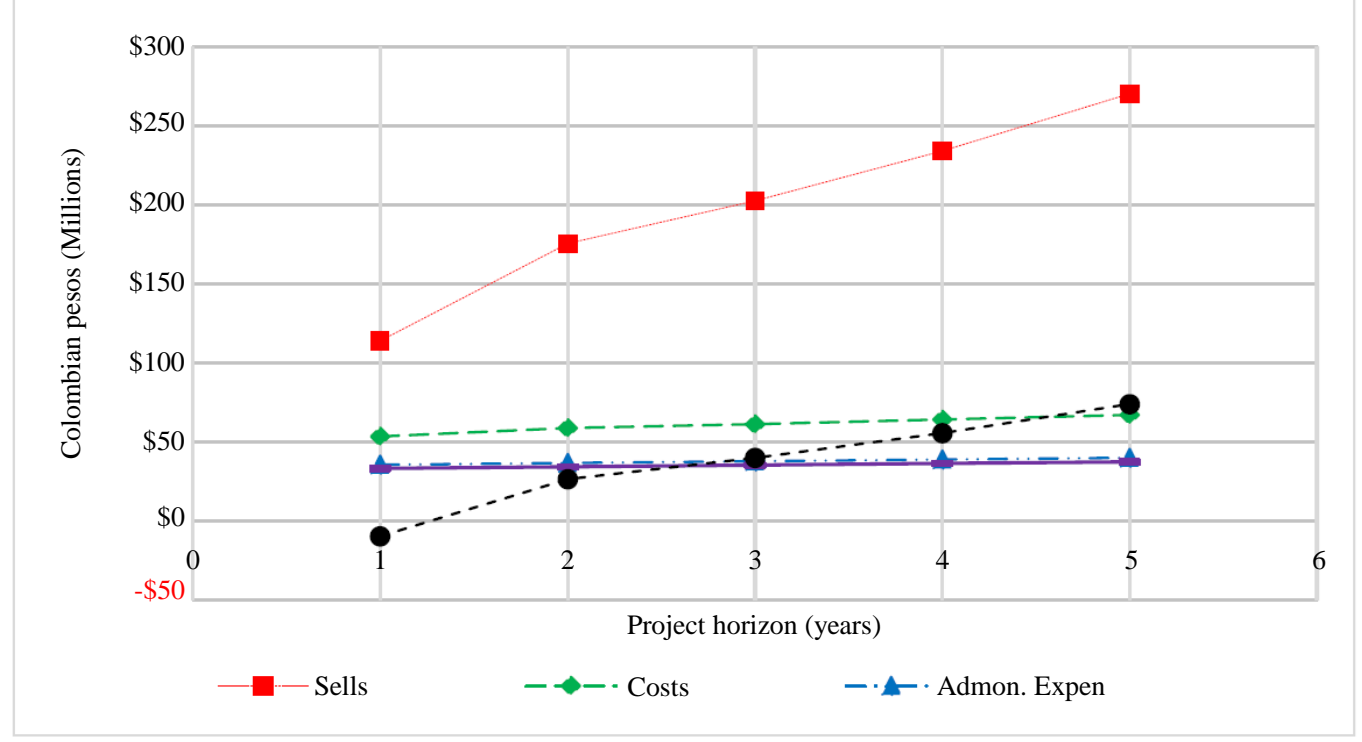

Fig. 1: Income statement performance

The opportunity cost is $10 \%$, initial investment is COP $\$ 41,785,620 ; \mathrm{NPV}$ is COP $\$ 442,067,710$, greater than zero; IRR is $136 \%$, greater than the opportunity cost and CBR is 11.58 , which is greater than 1 . In short, the project is feasible. It is important to compare indicators listed in Table 3 with studies previously conducted by other researchers.

A technical and financial feasibility study of organic waste-based fertilizers at Corabastos Market in Bogota, is carried out by (Baccar et al., 2019), who determined the financial feasibility of the project and considered it optimal, taking into account an Internal Rate of Return of $45.24 \%$, which is higher than the opportunity cost calculated in the financial study and also exceeds the current rate of return that was taken as a probable cost for the investor.

A business plan for the implementation of a materials recovery center in Guacimo, Costa Rica in 2008, concluded that the company would operate in an emerging industry, with a growing market that exceeds its production capacity, but there is room for improvement. After a five-year period, project's Net Present Value (NPV) is USD $\$ 123,440$, with no probability of obtaining a negative NPV (Sorathiya et al., 2014).

Another study on profitability of livestock waste management, carried out in Spain in 2000, shows that from a plant production capacity of 4,685 metric tons per year, profitability clearly rises, reaching NPV values of USD \$ 346,317, a return on investment of $10 \%$ and an IRR of 37\% (Mugwe et al., 2019). Similarly, as a result of this research, priority is given to the analysis from the consumer's financial point of view, since the final customer wants to have access to low prices. The most widely used agrochemical supply in 2016 at its minimum cost exceeds 23.5 times (and a maximum of 18 times) organic fertilizers available in the market. In addition to savings, this organic supply is good for the soil and the environment and beneficial for food security.

It is important to mention the increase in the demand and prices of agrochemicals in Colombia. According to The World Bank, this country was ranked 27th in 2002 with $302,000 \mathrm{~kg} / \mathrm{ha}$ of arable land and in 2014 , Colombia moved to the 9th place with $708.600 \mathrm{~kg} / \mathrm{ha}$ of arable land (Mugwe et al., 2019). According to Francisco Estupinan, president of the Colombian Stock Exchange, Colombia was the world's highest consumer of fertilizers per hectare of arable land in 2017 (Notarnicola et al., 2017). As expressed by South African researchers, the use of mineral and organic fertilizers applied alone or in combination contributes to alleviate the problem of soil fertility decline and the subsequent increase in crop yields (Kansiime et al., 2018).

A study on organic fertilizer marketing in the municipality of Pasto, Narino Department, identified benefits particularly related to the cost of organic fertilizers in contrast with chemicals. Information related to consumers' opinion about the use of organic fertilizers is collected. Among the advantages, 27\% of people mention its lower price compared to the chemical. Moreover, $23 \%$ of people say that organic fertilizer helps to improve soil physical properties. In addition, $15 \%$ note that the organic fertilizer lasts in the soil longer than the chemical fertilizer. Another similar percentage say that the organic fertilizer turns the soil into a nutrient reservoir; similarly $14 \%$ state that it is easily incorporated into the soil and $6 \%$ say that organic fertilizer could be produced in the farm (Eraso-Cabrera et al., 2014). 


\section{Identification of Market's Potential Demand for an Organic Product}

According to Colombia's National Statistics Department DANE (2015), 13,241,466 ha in Colombia are for agricultural use; 36,993,949 ha is used for livestock and 64,129,131 ha has other uses, for a total of $114,364,546$ ha. However, in the Cundinamarca Department, there has been a historic reduction in agricultural land use, which leads us to conduct a statistical forecast until 2021 to analyze this behavior. Such forecast is based on real data obtained from DANE. A linear regression is performed with the same data. Finally, a 6-year period is established as a baseline for the project's financial forecast (Fig. 2).

According to the results, the downward trend means a decrease in areas used for agriculture due to low investment levels in the agricultural sector; productivity has also been reduced by the weather factor. A first estimate of the regional market for organic fertilizers includes 6,700 ha as a potential market, plus the Cundinamarca Department with 150,000 ha approximately. $650 \mathrm{~kg}$ are required per hectare, which for the region represents 87,100 of $50-\mathrm{kg}$ bags and 1.95 million of $50-\mathrm{kg}$ bags for the Department, which defines the demand for the product. However, it is estimated that many conventional crop farmers will not purchase organic fertilizers, mainly because of a lack of knowledge regarding their benefits and production yield. Moreover, they do not have statistical data from market research showing the approximate demand for the product.

It is important to start an awareness campaign on organic food consumption. This process will take time, government support and relevant studies to promote dynamics that will allow the transition from conventional to agroecological farming. To improve product's market, agro-industrial processes should be encouraged via composting and the use of high volume of biodegradable waste produced by farms. Training farmers on the importance of composting and its comparative advantages is advised by (Eraso-Cabrera et al., 2014; Bosc et al., 2019; Escobar Escobar et al., 2013).

Another reference point is the study on (Penagos and Rodríguez, 2009), where researchers conclude that farmers in the Province of Sugamuxi (Boyaca Department, Colombia) are dissatisfied with the agricultural supplies they get in the market because their price is very high and performance fails to meet their expectations. The potential user demands safe, natural origin supplies, which are also chemical-free and contain a high nutritional value for local crops (Kleijn et al., 2019; Mokarram and Hojati, 2017).

Similarly, in (Gelgo et al., 2016) the author highlights the agricultural sector's activity, which accounts for $40 \%$ of the Gross Domestic Product and yet it is characterized by its low productivity. As an attempt to improve this situation, the Ethiopian government focused on promoting organic fertilizer adoption. However, empirical evidence on the impact of composting on farmers' incomes is absent in most parts of Ethiopia, specifically in the Shashemene District. The study focused on assessing the impact of organic fertilizer adoption on household farm income, showing an increase in farm income to farmers.

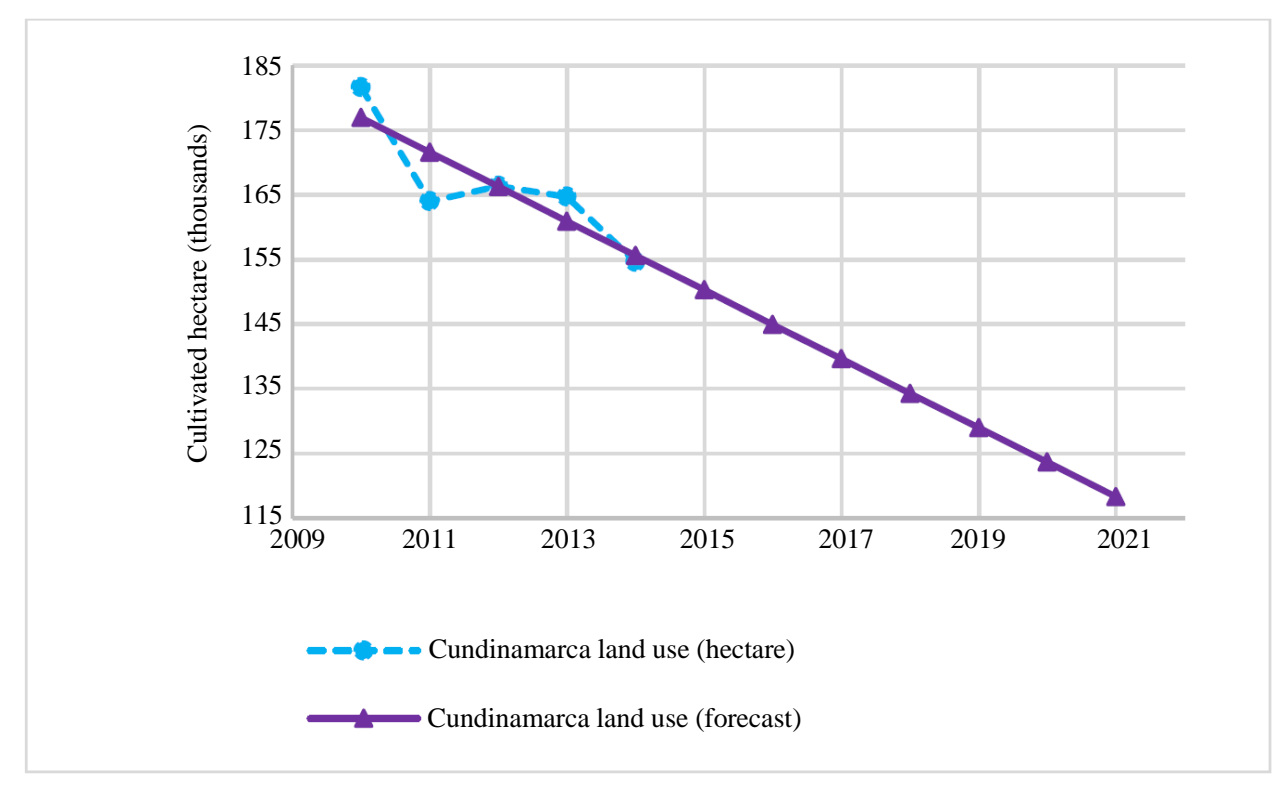

Fig. 2: Agricultural land use in the cundinamarca department 


\section{Conclusion}

The financial study showed investment benefits and opportunities in organic fertilizer production due to savings and low costs expectations. Composting is the most profitable product, since its low operating costs can generate more volume and profit over time and it can become a practice that promotes agroecological production systems.

\section{Acknowledgement}

We would like to thank Universidad de Cundinamarca for sponsoring the material and equipment required for the project development and providing us with the financial support to participate in scientific events that allowed us to present the preliminary results of this study.

\section{Author's Contributions}

Authors made equal contribution to this paper.

\section{Ethics}

Ethical principles related to scientific and academic research articles are observed.

\section{References}

Baccar, M., A. Bouaziz, P. Dugué, M. Gafsi and P.Y. Le Gal, 2019. The determining factors of farm sustainability in a context of growing agricultural intensification. Agroecol. Sustainable Food Syst., 43: 386-408.

DOI: $10.1080 / 21683565.2018 .1489934$

Bosc, P.M., J.M. Sourisseau, P. Bonnal, P. Gasselin and É. Valette et al., 2019. Diversity of Family Farming Around the World. In: Existence, Transformations and Possible Futures of Family Farms, Bosc, P.M., J.M. Sourisseau, P. Bonnal, P. Gasselin and É. Valette et al. (Eds.), Springer, ISBN-13: 978-94-024-1616-9.

Calle Hoyos, L., H. Paez Mozo and O. Parra Pradilla, 1995. [Characterization of UMATAS [Municipal Technical Assistance Units] technical assistants of Soto province [Colombia]].

Colombia, C.I., 2007. About Bogota. Colombia.

Dantzker, M.L., R.D. Hunter and S.T. Quinn, 2016. Research methods for criminology and criminal justice. J. Bartlett Learn.

Eraso-Cabrera, M., G. Zambrano-Burbano, F. TobarTello and H. Ojeda-Jurado, 2014. Agricultural evaluation of Brazilian grass Phalaris sp., in three municipalities of Nariño department, using organic fertilization. Agronomía, 22: 58-65.
Escobar Escobar, N., J. Mora Delgado and N. Romero Jola, 2013. Agronomic response of Zea mays 1. and phaseolus vulgaris L. to compost fertilization. Luna Azul, 37: 18-29.

Gelgo, B., P. Mshenga and L. Zemedu, 2016. Analysing the determinants of adoption of organic fertilizer by smallholder farmers in Shashemene District, Ethiopia. Int. J. Agric. Econom., 4: 117-124.

Giller, K., B. Vanlauwe and F. Kanamplu, 2020. The story of N2Africa: Putting nitrogen fixation to work for smallholder farmers in Africa: A flavour of the excitement and the richness of learning from N2Africa.

Henckel, L., L. Börger, H. Meiss, S. Gaba and V. Bretagnolle, 2015. Organic fields sustain weed metacommunity dynamics in farmland landscapes. Proc. Royal Society B: Biol. Sci., 282: 20150002-20150002. DOI: 10.1098/rspb.2015.0002

Kansiime, M.K., P. van Asten and K. Sneyers, 2018. Farm diversity and resource use efficiency: Targeting agricultural policy interventions in East Africa farming systems. NJAS-Wageningen J. Life Sci., 85: 32-41. DOI: 10.1016/j.njas.2017.12.001

Kleijn, D., R. Bommarco, T.P. Fijen, L.A. Garibaldi and S.G. Potts et al., 2019. Ecological intensification: Bridging the gap between science and practice. Trends Ecol. Evolut., 34: 154-166. DOI: $10.1016 /$ j.tree.2018.11.002

Lahmar, R., B.A. Bationo, N.D. Lamso, Y. Guéro and P. Tittonell, 2012. Tailoring conservation agriculture technologies to West Africa semi-arid zones: building on traditional local practices for soil restoration. Field Crops Res., 132: 158-167. DOI: $10.1016 /$ j.fcr.2011.09.013

Mokarram, M. and M. Hojati, 2017. Using Ordered Weight Averaging (OWA) aggregation for multicriteria soil fertility evaluation by GIS (case study: Southeast Iran). Comput. Electron. Agric., 132: 1-13. DOI: 10.1016/j.compag.2016.11.005

Mugwe, J., F. Ngetich and E.O. Otieno, 2019. Integrated soil fertility management in Sub-Saharan Africa: Evolving paradigms toward integration.

Mujica, P.M.T., C. Arraño, R. Vera, L. Robles and C. del Río et al., 2019. Perspectives of abandonment/continuity of typological groups of sheep farms in the semi-arid region of Central Chile. Economía Agrariay Recursos Naturales, 19: 113-132. DOI: 10.7201/earn.2019.02.06

Murillo, J., J. Yeomans and J. Montero, 2008. Business plan for the implementation of a material recovery center in Guácimo, Costa Rica.

Notarnicola, B., S. Sala, A. Anton, S.J. McLaren and E. Saouter et al., 2017. The role of life cycle assessment in supporting sustainable agri-food systems: A review of the challenges. J. Cleaner Produc., 140: 399-409. DOI: 10.1016/j.jclepro.2016.06.071 
Nowak, B., T. Nesme, C. David and S. Pellerin, 2015 Nutrient recycling in organic farming is related to diversity in farm types at the local level. Agric. Ecosyst. Environ., 204: 17-26.

DOI: $10.1016 /$ j.agee.2015.02.010

Pandit, N.R., H.P. Schmidt, J. Mulder, S.E. Hale and O. Husson et al., 2020. Nutrient effect of various composting methods with and without biochar on soil fertility and maize growth. Archives Agronomy Soil Sci., 66: 250-265.

DOI: $10.1080 / 03650340.2019 .1610168$

Penagos, C.O.P. and J.M.H. Rodríguez, 2009. Situación actual de la comercialización del abono orgánico bocashi en el Sugamuxi. Cuadernos Admin., 25: 141-154. DOI: 10.25100/cdea.v25i42.419

Rasmussen, L.V., R. Bierbaum, J.A. Oldekop and A. Agrawal, 2017. Bridging the practitioner- researcher divide: Indicators to track environmental, economic and sociocultural sustainability of agricultural commodity production. Global Environ. Change, 42: 33-46. DOI: 10.1016/j.gloenvcha.2016.12.001
Romero, N., N. Escobar and C. Jaramillo, 2019. Typology of small producers in transition to agroecological production.

Serna, L.D., J.S. Toro, S.S. Loaiza, Y.C. Perez and C.C. Alzate, 2016. Agricultural waste management through energy producing biorefineries: The Colombian case. Waste Biomass Valorization, 7: 789-798. DOI: 10.1007/s12649-016-9576-3

Sorathiya, L., A. Fulsoundar, K. Tyagi, M. Patel and R. Singh, 2014. Eco-friendly and modern methods of livestock waste recycling for enhancing farm profitability. Int. J. Recycling Organic Waste Agric.

Szeląg-Sikora, A. and M. Cupiał, 2014. Dynamics of organic farming development and its subsidizing. Agric. Eng. 